\title{
Short Communication: The fruit plant species diversity in the home gardens and their contribution to the livelihood of communities in rural area
}

\author{
ELFRIDA, ALBIAN MUBARAK, ADI BEJO SUWARDI" \\ Department of Biology Education, Faculty of Teacher and Training Education, Universitas Samudra. Jl. Meurandeh, Kota Langsa 24416, Aceh, \\ Indonesia. Tel.: +62-641-426535. •email: adi.bsw@gmail.com
}

Manuscript received: 28 June 2020. Revision accepted: 21 July 2020.

\begin{abstract}
Elfrida, Mubarak A, Suwardi AB. 2020. Short Communication: The fruit plant species diversity in the home gardens and their contribution to the livelihood of rural communities in Tenggulun Sub-district, Aceh Tamiang, Indonesia. Biodiversitas 21: $3670-3675$. Home gardens have a significant potential to improve food security and offer a contribution to household income for communities in rural areas. The aim of this study was to assess the diversity of fruit plant species in the home gardens and their contribution to the livelihood of rural communities in Tenggulun Sub-district, Indonesia. The study was conducted in three villages of Tenggulun Subdistrict, Aceh Tamiang District, namely Tenggulun, Selamat, and Simpang Kiri. Extensive field surveys, plant collections, and interviews with local communities were conducted, involving 350 households, using random sampling methods. A total of 39 fruit plant species consisting of 23 genera and 17 families were recorded at the three villages. Sixteen species, i.e., A. muricata, A. jiringa, Artocarpus integer, Averrhoa bilimbi, Baccaurea motleyana, Carica papaya, Citrus aurantifolia, Citrus hystrix, Garcinia mangostana, Mangifera indica, Manilkara zapota, Musa x paradisiaca, Nephelium lappaceum, Psidium guajava, Spondias pinnata, and Syzygium aqueum were the most frequently recorded in all of the villages. In addition to being used as food, the fruit plants in the study area were also used as medicines, fodder, fuelwood, and household items. The fruit plant species have a significant role in supporting household livelihoods to improve food security and potentially offer a household income for the rural community in the study area.
\end{abstract}

Keywords: Home garden, fruit plants, species diversity, species richness, Tenggulun

\section{INTRODUCTION}

Home garden is generally described as a land-use system encompassing the purposeful management of multipurpose trees and shrubs in close relationship with annual and perennial crop plants and, usually, livestock within individual house compounds, the entire tree-animal crop unit being widely managed by the family labor force (Wiersum 2006). It is rich in biodiversity, including wild plants and the cultivated ones (Kumar and Nair 2004; Moreno-Calles et al. 2010), and plays an important role in rural communities in many aspects, including the economy, ecology, and culture (Méndez et al. 2001; Senanayake et al. 2009; van Heezik et al. 2014). The plants in the home garden provide a source for a variety of medicinal and ceremonial materials. Therefore, it becomes a valuable source of direct or indirect income for the owner. In addition, home garden has an ecological function to conserve water, prevent erosion (Senanayake et al. 2009; Larios et al. 2013), conserve biodiversity (Kehlenbeck and Maass 2004; Kaswanto and Nakagoshi 2012), and store carbon (Kaswanto and Nakagoshi 2012). Home garden is also used by the community as a place to transfer local knowledge about ecology and utilization of plants (Méndez et al. 2001; Thomas et al. 2008).

The rural communities in the Tenggulun Sub-district generally have large home gardens, planted with various species of vegetables, fruits, and tuberous plants. Vegetables and tubers rich in fiber, nutrition, and bioactive compounds are very important for maintaining human health (Kusharto 2006; Suwardi et al. 2018), while fruit plants are rich in nutrition to ensure food quality and dietary diversity and can also provide household income (Bvenura and Sivakumar 2007; Mwema et al. 2012; Mabaya et al. 2014; Navia et al. 2015; Khruomo and Deb 2018; Abebe et al. 2019; Suwardi et al. 2019; Suwardi et al. 2020a). However, home gardens in the Tenggulun Sub-district have not been evaluated for their species composition. Therefore, the composition of fruit plants in the home gardens and their contribution to the livelihoods of local communities need to be investigated. This may fill the information gap on fruit plant species through assessing fruit tree species diversity in the home gardens and their contribution to the livelihood (Abebe et al. 2019). The aim of this study was to assess the diversity of fruit plant species in the home gardens and their contribution to the livelihood of rural communities in Tenggulun Sub-district, Indonesia.

\section{MATERIALS AND METHODS}

\section{Study area}

The study was conducted in the Aceh Tamiang District, Aceh Province, Indonesia consisting of three villages, namely Tenggulun, Selamat, and Simpang Kiri (Figure 1). Tenggulun Sub-district is one of the twelve sub-districts of 
Aceh Tamiang District, located at $4^{\circ} 00^{\prime} 47.3^{\prime \prime} \mathrm{N}$ and 97 $55^{\prime} 51.0 " \mathrm{E}$. It is $28 \mathrm{~km}$ from Kuala Simpang, the capital of the Aceh Tamiang District. Its population is 291,112, of whom 146,794 are men and 144,318 women. A total of 3,802 households live in the Selamat, Tenggulun, and Simpang Kiri Village. The climate type of the Tenggulun Sub-district is humid tropic, with mean annual rainfall ranging from $406 \mathrm{~mm}$ to $2886 \mathrm{~mm}$, and the average daily temperature of $29^{\circ} \mathrm{C}$. The altitudes of Tamiang District range from $500 \mathrm{~m}$ to $700 \mathrm{~m}$ and the topography of the study area is mountainous (Central Bureau of Statistics of Aceh Tamiang District 2019).

\section{Data collection}

Information on fruit plant species was obtained through participatory observations and semi-structured interviews with informants. A total of 350 households (Table 1) were selected using a random sampling method. The interview took place face to face in the Indonesian language, and each interview lasted between 20 and 30 minutes.

Samples of all fruit plants were collected together with the recording of their vernacular names, number of individuals, habits, and use. In addition, botanical identification was performed at the Biology Laboratory, Samudra University, Aceh, Indonesia. The botanical names have been updated using The Plant List (www.theplantlist.org) and the International Plant Name Index (www.ipni.org).

\section{Data analysis}

Fruit tree species diversity in home gardens in the study area was determined using the Shannon-Wiener Index $\left(\mathrm{H}^{\prime}\right)$ calculated using the following formula (Barbour et al. 1987).

$$
H^{\prime}=-\sum_{i=1}^{s}(P \hat{i}) \ln (P \hat{i})
$$

Where $\mathrm{H}^{\prime}=$ Shannon-Wiener Diversity Index, $\mathrm{s}=$ number of species $\mathrm{Pi}=$ the proportion of individuals or abundance of the $\mathrm{i}$ species expressed as the proportion of the total abundance $\mathrm{ln}=$ natural logarithm of $\mathrm{Pi}$.

\section{Evenness (Equitability) index ( $\left.J^{\prime}\right)$}

Evenness (Shannon equitability) index ( $\left.\mathrm{J}^{\prime}\right)$ calculated using the following formula (Marguran 2004).

$$
I^{\prime}=\frac{H^{\prime}}{H_{\max }}=\frac{H^{\prime}}{\ln S}
$$

Where; J' = Evenness, H' = Shannon-Wiener Diversity Index; $\mathrm{S}=$ total number of species in the sample; $\ln =$ natural logarithm.

Table 1. Sample distribution of respondents in the study area

\begin{tabular}{lccc}
\hline Village & $\begin{array}{c}\text { Total no. of } \\
\text { households }\end{array}$ & $\begin{array}{c}\text { The sample of } \\
\text { households }\end{array}$ & $\begin{array}{l}\text { Percentage } \\
(\%)\end{array}$ \\
\hline Tenggulun & 2,019 & 200 & 10 \\
Selamat & 1,285 & 100 & 8 \\
Simpang Kiri & 498 & 50 & 10 \\
Total & 3,802 & 350 & \\
\hline
\end{tabular}

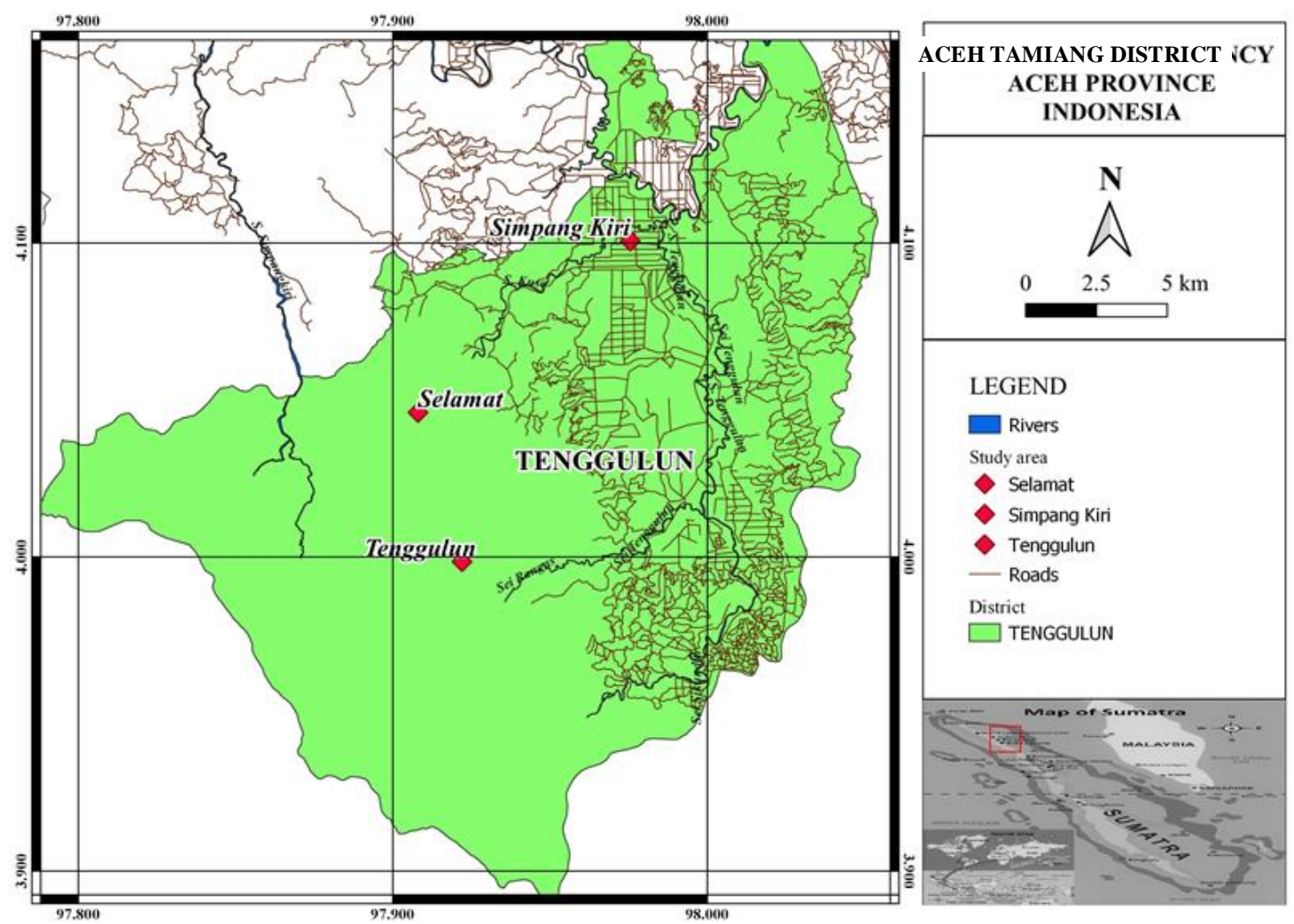

Figure 1. Map of Aceh Tamiang District, Aceh Province, Indonesia, showing the study area 


\section{RESULTS AND DISCUSSION}

\section{Floristic composition of fruit plant species}

A total of 39 fruit plant species represented by 23 genera and 17 families were recorded at the three villages (Table 2).

The highest number of fruit plant species was recorded in Tenggulun, i.e., 34 species, followed by Selamat 27 species and Simpang Kiri 23 species. The number of species recorded in this study (39 species from 150 home gardens) was comparable to the 40 fruit plant species reported in the Hintalo Wejerat district (Tsegazeabe et al. 2012), but lower than that in Kerala, India, i.e., 86 species (George and Cristopher 2019) and in the Jabon Mekar village, Bogor District, Indonesia, i.e., 57 species (Prasetyo
2007). However, it was higher than the 30 species of fruit plants growing in the home garden of North Sumatra, Indonesia (Silalahi and Nismawati 2018), 30 species in Langsa, Aceh, Indonesia (Navia et al. 2017), 18 species in the Burie District, Ethiopia (Abebe et al. 2019), 13 species in South-Western Ethiopia (Mathewos et al. 2018), and 4 species in Bulen District, North-Western Ethiopia (Beyene et al. 2018). This variation in the diversity of fruit plant species was affected by the home garden size and the culture of the local community in the study area (Arora and Anjula 1996). The significant correlation between home garden size and species diversity was observed by Das and Das (2005) in India and Sunwar (2003) in Nepal.

Table 2. Species, genus, and family of fruit plant species in the study area

\begin{tabular}{|c|c|c|c|c|}
\hline Botanical name & Family & Local name & Life form & Location \\
\hline Anacardium occidentale $\mathrm{L}$. & Anacardiaceae & Jambu mete & Tree & $\mathrm{TG}, \mathrm{SL}$ \\
\hline Annona muricata $\mathrm{L}$. & Annonaceae & Sirsak & Tree & TG, SL, SK \\
\hline Annona squamosa $\mathrm{L}$. & Annonaceae & Srikaya & Tree & TG \\
\hline Archidendron jiringa (Jack) Neil & Mimosaceae & Jengkol & Tree & TG, SL, SK \\
\hline Artocarpus altilis (Parkinson ex F.A.Zorn) Fosberg & Moraceae & Sukun & Tree & TG, SK \\
\hline Artocarpus camansi Blanco & Moraceae & Keluih & Tree & TG \\
\hline Artocarpus integer (Thunb.) Merr. & Moraceae & Cempedak & Tree & TG, SL, SK \\
\hline Artocarpus heterophyllus Lam. & Moraceae & Nangka & Tree & TG, SL \\
\hline Averrhoa bilimbi L. & Oxalidaceae & Belimbing Wuluh & Tree & TG, SL, SK \\
\hline Averrhoa carambola $\mathrm{L}$. & Oxalidaceae & Belimbing Besar & Tree & TG \\
\hline Baccaurea motleyana (Mull.Arg) Mull.Arg & Phyllantaceae & Rambai & Tree & TG, SL, SK \\
\hline Carica papaya $\mathrm{L}$ & Caricaceae & Pepaya & Herb & TG, SL, SK \\
\hline Citrus amblycarpa (Hassk.) Ochse & Rutaceae & Jeruk Kesturi & Tree & SL \\
\hline Citrus aurantifolia (Christm.) Swingle & Rutaceae & Jeruk Nipis & Tree & TG, SL, SK \\
\hline Citrus hystrix DC & Rutaceae & Jeruk Purut & Tree & TG, SL, SK \\
\hline Citrus maxima (Burm.) Merr & Rutaceae & Jeruk Bali & Tree & TG, SK \\
\hline Citrus sinensis $\mathrm{L}$ & Rutaceae & Jeruk Manis & Tree & TG, SL \\
\hline Dimocarpus longan $\mathrm{L}$ & Sapindaceae & Kelengkeng & Tree & SL \\
\hline Durio zibethinus L. & Malvaceae & Durian & Tree & TG, SK \\
\hline Eleiodoxa conferta (Griff) Burret & Arecaceae & Salak Hutan & Palm & TG \\
\hline Garcinia mangostana $\mathrm{L}$ & Clusiaceae & Manggis & Tree & TG, SL, SK \\
\hline Lansium parasiticum (Osbeck) K.C.Sahni \& Bennet & Meliaceae & Lansat & Tree & SL \\
\hline Mangifera foetida $\mathrm{L}$. & Anacardiaceae & Mancang & Tree & SL, SK \\
\hline Mangifera indica $\mathrm{L}$. & Anacardiaceae & Mangga & Tree & TG, SL, SK \\
\hline Mangifera laurina Blume & Anacardiaceae & Asam Pauh & Tree & TG, \\
\hline Mangifera odorata Griff. & Anacardiaceae & Kuweni & Tree & TG, SK \\
\hline Manilkara zapota (L.) P.Royen & Sapotaceae & Sawo & Tree & TG, SL, SK \\
\hline Musa x paradisiaca $\mathrm{L}$. & Musaceae & Pisang & Herb & TG, SL, SK \\
\hline Musa textilis Nee & Musaceae & Pisang Raja & Herb & TG, SL \\
\hline Neolamarckia cadamba (Roxb.) Bosser & Rubiaceae & Jabon & Tree & SL \\
\hline Nephelium lappaceum $\mathrm{L}$. & Sapindaceae & Rambutan & Tree & TG, SL, SK \\
\hline Pometia pinnata J.R.Forst. \& G.Forst. & Sapindaceae & Boh Keulayu & Tree & $\mathrm{TG}, \mathrm{SL}$ \\
\hline Psidium guajava $\mathrm{L}$. & Myrtaceae & Jambu Biji & Tree & TG, SL, SK \\
\hline Salacca zallaca (Gaertn.) Voss & Arecaceae & Salak & Palm & TG \\
\hline Sandoricum koetjape (Burm.f.) Merr. & Meliaceae & Setui & Tree & TG, SK \\
\hline Spondias pinnata (L. f.) Kurz & Anacardiaceae & Kedondong & Tree & TG, SL, SK \\
\hline Syzygium aqueum (Burm.f.) Alston & Myrtaceae & Jambu Air & Tree & TG, SL, SK \\
\hline Syzygium malaccense (L.) Merr. \& L.M.Perry & Myrtaceae & Jambu Bol Merah & Tree & TG, SL \\
\hline Syzygium samarangense (Blume) Merr. \& L.M.Perry & Myrtaceae & Jambu Air Merah & Tree & TG, SK \\
\hline
\end{tabular}




\section{Frequency of fruit tree species}

The frequency of each species across the study area is shown in Figure 2. Sixteen species, i.e., A. muricata, A. jiringa, A. integer, A. bilimbi, B. motleyana, C. papaya, $C$. aurantifolia, C. hystrix, G. mangostana, M. indica, M. zapota, M. paradisiaca, $N$. lappaceum, $P$. guajava, $S$. pinnata, and $S$. aqueum were the most frequently recorded fruit plant species in all of the villages. On the other hand, 4 fruit plant species, i.e., C. amblycarpa, D. longan, $L$. parasiticum, and N. cadamba, were found only in Selamat village, and 6 species, i.e., A. squamosa, A. camansi, A. carambola, E. conferta, S. zallaca, and M. laurina, were found only in Tenggulun Village.
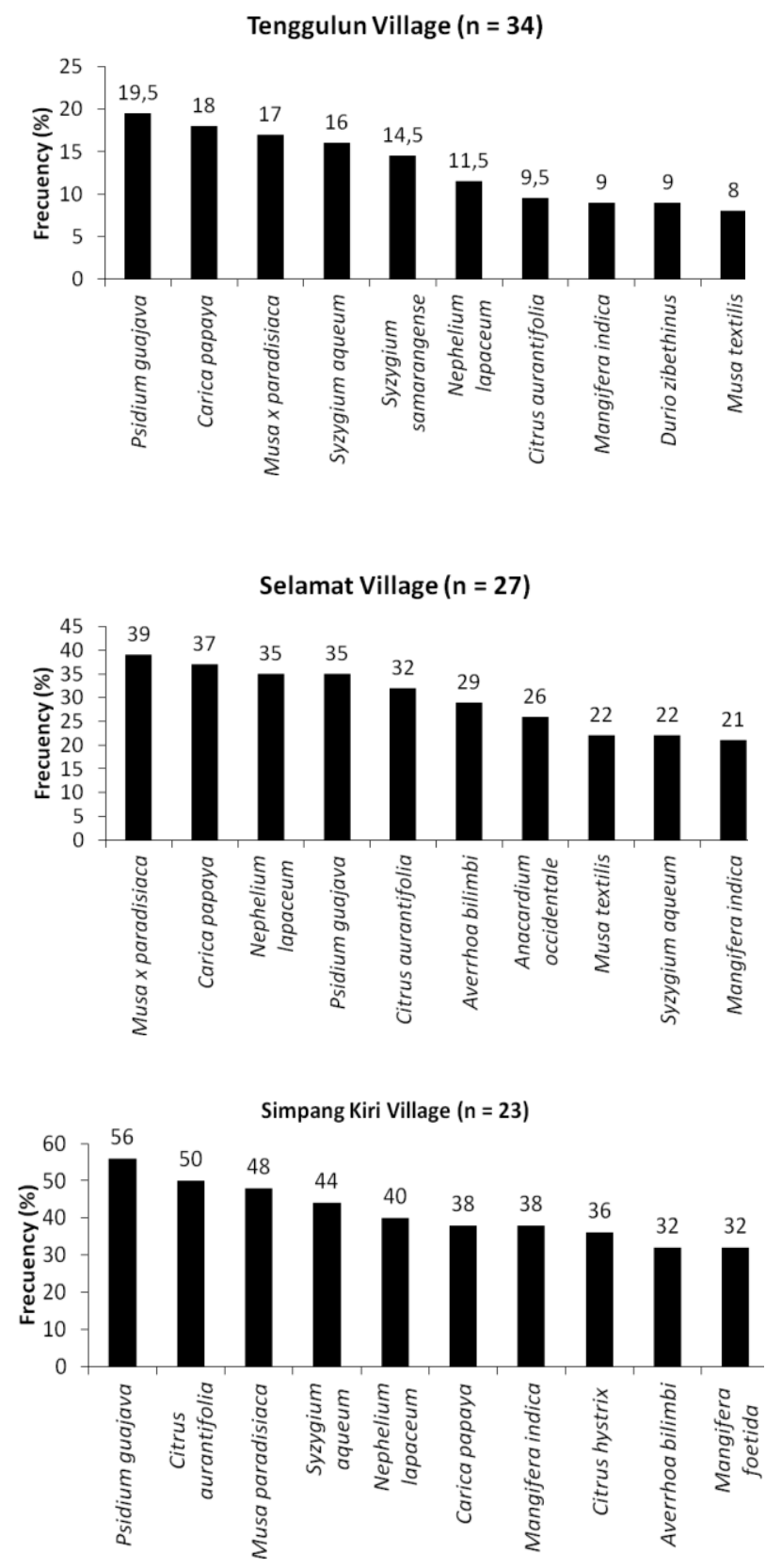

Figure 2. The frequency of each species in the study area
Of the total fruit plant species recorded in the Tenggulun Village, $P$. guajava was the most frequently recorded species with a frequency of $19.5 \%$, followed by C. papaya $18 \%$ and $M$. paradisiaca $17 \%$, while in Selamat Village $M$. paradisiaca and $C$. papaya with frequency of $39 \%$ and $37 \%$, respectively, and in Simpang Kiri Village $P$. guajava (56\%), C. aurantifolia (50\%), and M. paradisiaca (48\%). Generally, P. guajava and $C$ aurantifolia were the most frequently recorded fruit plant species in the household home garden. The results of this study were similar to those of Navia et al. (2017) and Yuliawati et al. (2016) that $M$. paradisiaca was commonly planted by rural communities in home gardens. Fruit plants and vegetables are the most common in the home gardens to provide a source of food (Tefera et al. 2015).

\section{Fruit plant species diversity}

Fruit plant species diversity was higher in Selamat village than in Simpang Kiri and Tenggulun (Table 3). The highest Shannon diversity index was recorded in Selamat village (3.03), while the highest species evenness was recorded in Simpang Kiri Village (0.95). The Shannon Diversity Index showed that the home gardens in all villages had $H^{\prime}$ values between 2.95 and 3.03. This indicated that the fruit plant species diversity index in the study area was categorized as medium (Barbour et al. 1987). However, a different finding was reported by Prasetyo (2007) that the fruit diversity in the home garden of Jabon Mekar Village, Bogor, Indonesia was high.

\section{Contribution of fruit plant species to household's livelihoods}

The home gardens of the study area were planted with annual and perennial fruit plants, which are the main source of food for the households to meet dietary needs. The communities in the study area grew different plant species in their home gardens mainly for household consumption and, to a limited extent, for the income generation. The results of this study were consistent with the study reported by Abebe et al. (2019) in Burie District, Ethiopia, where fruit plant species in the home gardens were primarily used for consumption by themselves. The fruit plants are rich in nutrition to ensure food quality and dietary diversity to the maintenance of human health (Mabaya et al. 2014; Khruomo and Deb 2018; Suwardi et al. 2019; Navia et al. 2019). Most rural communities have received income from selling various fruits in the traditional market (Navia et al. 2020; Suwardi et al. 2020b; Suwardi et al. 2020c).

In addition to being used as food, fruit plants from the home gardens were also used as feed for animals (9 species), fuelwood (5 species), medicine (5 species), and household items (5 species) (Table 4$)$.

Table 3. The Shannon diversity and evenness indexes of three villages in the study area

\begin{tabular}{lccc}
\hline Village & Richness & Shannon (H') & Evenness \\
\hline Tenggulun & 34 & 2.95 & 0.84 \\
Selamat & 27 & 3.03 & 0.92 \\
Simpang Kiri & 23 & 2.98 & 0.95 \\
\hline
\end{tabular}


Tabel 4. Other uses of the fruit plant species in the study area

\begin{tabular}{ll}
\hline Uses & Species \\
\hline Medicine & Annona muricata, Averrhoa bilimbi, Carica papaya, Citrus aurantifolia, Psidium guajava \\
Fodder & Archidendron jiringa, Artocarpus altilis, Artocarpus camansi, Artocarpus integer, Artocarpus heterophyllus, \\
& Musa x paradisiaca, Neolamarckia cadamba, Spondias pinnata, Syzygium aqueum \\
Fuelwood & Archidendron jiringa, Durio zibethinus, Lansium parasiticum, Neolamarckia cadamba, Pometia pinnata \\
Household items & Archidendron jiringa, Durio zibethinus, Neolamarckia cadamba, Spondias pinnata, Syzygium aqueum \\
\hline
\end{tabular}

Approximately $23.43 \%$ of respondents used leaves of several species, such as A. heterophyllus, M. paradisiaca, and $S$. pinnata, as fodder for goats in particular because of the high content of starch and metabolizable energy which gives livestock better digestibility (Amalina et al. 2020). A total of $52 \%$ of respondents traditionally used several species, such as A. bilimbi fruit, for cough treatment. Fruit extracts of $A$. bilimbi contain bioactive compounds such as saponin (Wahab et al. 2009; Kumar et al. 2011) known to have antitussive and expectorant effects for effective treatment of coughs (Roy et al. 2011; Hasim et al. 2019).

Fuelwood is the main source of energy for $68.85 \%$ of the respondents in the study area. They harvest firewood from the home gardens to prepare any food. A. jiringa and $N$. cadamba were the most preferred firewood by the respondents in the study area. Other popular materials used by respondents in the home garden are wood for handles of various tools and household utensils. D. zibethinus was the most common species whose wood was used by respondents for furniture and household utensils such as tables, chairs, beds, doors, or windows.

The results of this study highlight the significant function of fruit plants in supporting household livelihoods in a variety of ways, including food supplies, medicines, animal feed, fuelwood, and household items. Home gardens contribute significantly to the food supply, especially for rural communities, due to the high production and diversity of cultivated edible species (Tynsong and Tiwari 2010). Proper management of home gardens has a significant potential to improve food security and offers a contribution to household income in the study area. In addition, the integration of scientific management into indigenous knowledge may promote rural agriculture in the Aceh Tamiang District.

\section{ACKNOWLEDGEMENTS}

We are grateful to all people in the studied villages for their kind hospitality and share of knowledge. We are also grateful that the University of Samudra, Langsa City, Aceh, Indonesia has supported this study.

\section{REFERENCES}

Abebe A, Kiros H, Sorecha EM. 2019. Assessing fruit tree species diversity in home garden agroforestry and their role supporting local people's livelihoods in Burie District, Ethiopia. Turkish J Agriculture - Food Science and Technology 7 (7): 946-954

Amalina IF, Haziq JM, Syukor ARA, Rashid AHM, Izzati KAN. 2020. Formulation of Capra hircus feeds to utilize Artocarpus heterophyllus leaves and palm acid oil (PAO). IOP Conf Ser Mater Sci Eng 736: 022016. DOI: 10.1088/1757-899X/736/2/022016.

Arora RK, Anjula P. 1996. Wild edible plants of India: diversity conservation and use. ICAR, New Delhi, India

Barbour GM, Burk JK, Pitts WD. 1987. Terrestrial Plant Ecology. The Benyamin/Cummings Publishing Company, USA.

Beyene M, Mohammed M, Nigatu L. 2018. Plant Species Diversity and structure in homegarden agroforestry systems of Bulen District, North-Western Ethiopia. Agric For Fish 7 (3): 121-132.

Bvenura C, Sivakumar D. 2007. The role of wild fruits and vegetables in delivering a balanced and healthy diet. Food Res Intl 99 (2019): 15-30

Das T, Das AK. 2005. Inventorying plant biodiversity in homegardens: a case study in Barak Valley, Assam, North East India. Curr Sci 89 (1): 155-163.

George MV, Christopher G. 2019. Structure, diversity and utilization of plant species in tribal homegardens of Kerala, India. Agroforest Syst 94: 297-307

Hasim, Arifin YY, Andrianto D, Faridah DN. 2019. Ethanol extracts of Averrhoa bilimbi leaf demonstrated antioxidative and antiinflammatory activity. Jurnal Aplikasi Teknologi Pangan 8 (3): 86-93 [Indonesian]

Kaswanto, Nakagoshi N. 2012. Revitalizing home gardens, a small agroforestry landscape for a low carbon society. Hikobia 16: 161-171

Kehlenbeck K, Maass BL. 2004. Crop diversity and classification of homegardens in Central Sulawesi, Indonesia. Agrofor Syst 63 (1): 5362.

Khruomo N, Deb CR. 2018. Indigenous wild edible fruits: sustainable resources for food, medicine and income generation - A study from Nagaland, India. J Exp Biol Agric Sci 6 (2): 405-413.

Kumar BM, Nair PKR. 2004. The enigma of tropical homegardens. Agrofor Syst 61: 135-152.

Kumar AS, Kavimani S, Jayaveera KN. 2011. A review on medicinal plants with potential antidiabetic activity. Intl J Phytopharmacol 2 (2): 53-60.

Kusharto CM. 2006. Dietary fiber and its role for health. Jurnal Gizi dan Pangan 1 (2): 45-54. [Indonesian]

Larios C, Casas A, Vallejo M, Moreno-Calles AI, Blancas J. 2013. plant management and biodiversity conservation in Náhuatl homegardens of the Tehuacán Valley, Mexico. J Ethnobiol Ethnomed 9 (74): 1-16.

Mabaya E, Jackson J, Ruethling G, Carter CM, Castle J. 2014. Wild fruits of Africa: Commercializing natural products to improve rural livelihoods in southern Africa. Intl Food Agribus Man 17B (B): 69-74

Margurran AE. 2004. Measuring Biological Diversity. Blackwell Publishing, Oxford, UK

Mathewos M, Hundera K, Biber-Freudenberger L. 2018. Planting Fruits and vegetables in homegarden as a way to improve livelihoods and conserve plant biodiversity. Agriculture 8 (12): 190.

Méndez VE, Lok R, Somarriba E. 2001. Interdisciplinary analysis of homegardens in Nicaragua: Micro-zonation, plant use and socioeconomic importance. Agrofor Syst 51 (2): 85-96.

Moreno-Calles A, Casas A, Blancas J, Caballero J, Garcia-Barrios L, Perez-Negron E, Ragel-Landa S. 2010. Agroforestry systems and biodiversity conservation in arid zones: the case of the Tehuacán Valley, Central México. Agrofor Syst 80 (3): 315-331.

Mwema CM, Mutai BK, Lagat JK, Kibet LK, Maina MC. 2012. Contribution of selected indigenous fruits on household income and food security in Mwingi, Kenya. Curr Res J Soc Sci 4 (6): 425-430 
Navia ZI, Chikmawati T. 2015. Durio tanjungpurensis (Malvaceae), a new species and its one new variety from West Kalimantan, Indonesia. Bangladesh J Bot 44 (3): 429-436

Navia ZI, Suwardi AB, Saputri A. 2017. Tracking species diversity of crops fruit as nutrition sources for communities in Langsa, Aceh. In Agustien A, Syaifullah, Pitopang R, Nurainas, Ilyas S, Kurniawan R. (eds.) Proc. Sem. Nas. Biodiversitas dan Ekologi Tropika Indonesia Ke-4 dan Kongres Penggalang Taksonomi Tumbuhan Indonesia Ke12, Padang. [Indonesian]

Navia ZI, Suwardi AB, Saputri A. 2019. Characterization of local fruits in the Leuser Ecosystem of Aceh Tamiang District, Aceh. Bul Plasma Nutfah 25 (2): 133-142.

Navia ZI, Suwardi AB, Harmawan T, Syamsuardi, Mukhtar E. 2020. The diversity and contribution of indigenous edible fruit plants to the rural community in the Gayo Highlands, Indonesia. J Agric Rural Dev Tropics Subtropics 121 (1): 89-98.

Prasetyo. 2007. Fruit of plant diversity at home-garden of Jabon Mekar village, subdistrict of Parung, Bogor District. Biodiversitas 8 (1): 43 47

Roy A, Geetha RV, Lakshmi T. 2011. Averrhoa bilimbi Linn-Nature's drug store- a pharmacological review. Intl J Drug Dev Res 3 (3): 101106.

Senanayake RL, Sangakkara UR, Pushpakumara DKNG, Stamp P. 2009. Vegetation composition and ecological benefits of home gardens in the Meegahakiula Region of Sri Lanka. Trop Agric Res 21 (1): 1-9.

Silalahi S, Nisyawati. 2018. The ethnobotanical study of edible and medicinal plants in the home garden of Batak Karo sub-ethnic in North Sumatra, Indonesia. Biodiversitas 19 (1): 229-238.

Sunwar S, Thornstrom CG, Subdeb A, Bystrom M. 2006. Homegardens in western Nepal: opportunities and challenges for on-farm managemen of agro-biodiversity. Biodivers Conserv 15 (13): 4211-4238.

Suwardi AB, Indriaty, Navia ZI. 2018. Nutritional evaluation of some wild edible tuberous plants as an alternative food. Innovare J Food Sci 6 (2): 9-12.

Suwardi AB, Navia ZI, Harmawan T, Syamsuardi, Mukhtar E. 2019. The diversity of wild edible fruit plants and traditional knowledge in West Aceh region, Indonesia. J Med Plants 7 (4): 285-290.

Suwardi AB, Navia ZI, Harmawan T, Nuraini, Syamsuardi, Mukhtar E. 2020a. Ethnobotany, nutritional composition and sensory evaluation of Garcinia from Aceh, Indonesia. IOP Conf Ser Mater Sci Eng 725 (1): 012064. DOI: 10.1088/1757-899X/725/1/012064.

Suwardi AB, Navia ZI, Harmawan T, Syamsuardi, Mukhtar E. 2020b. Ethnobotany and conservation of indigenous edible fruit plants in South Aceh, Indonesia. Biodiversitas 21 (5): 1850-1860

Suwardi AB, Navia ZI, Harmawan T, Syamsuardi, Mukhtar E. 2020c. Wild edible fruits generate substantial income for local people of the Gunung Leuser National Park, Aceh Tamiang Region. Ethnobot Res Appl 20: 1-13.

Tefera M, Mirutse G, Ensermu K. 2015. Ethnobotanical study of homegarden plants in Sebeta-Awas District of the Oromia Region of Ethiopia to assess use, species diversity and management practices. J Ethnobiol Ethnomed 11 (1): 64

The Central Bureau of Statistics of Aceh Tamiang District. 2019. Tenggulun Sub-district in figure 2019. The Central Bureau of Statistics of Aceh Tamiang District, Aceh Tamiang District, Indonesia

Thomas E, Vandebroek I, Goetghebeur P, Sanca S, Arrazola S, Van DP. 2008. The relationship between plant use and plant diversity in the Bolivian Andes, with special reference to medicinal plant use. Human Ecol 36 (6): 861-879.

Tsegazeabe H, Haileselasie M, Mekonen T, Ghiwot G, Gebremichael E, Solomon A. 2012. Hiluf agroforestry practices and biodiversity management in backyards in Hiwane, Hintalo Wejerat of Tigray, Northern Ethiopia. Asian J Agric Sci 4 (2): 110-116.

Tynsong HB, Tiwari K. 2010. Plant diversity in the homegardens and their significance in the livelihoods of War Khasi community of Meghalaya, North- East India. J Biodivers 1 (1): 1-11.

van Heezik YM, Dickinson KJM, Freeman C, Porter S. 2014. Native and exotic woody vegetation communities in domestic gardens in relation to social and environmental factors. Ecol Soc 19 (4): 17

Wahab NHBA, Effendy M, Mariam, Zuraida W, Aqilah S. 2009. Phytochemical screening and antimicrobial efficacy of extracts from Averrhoa bilimbi (Oxalidaceace) fruits against human pathogenic bacteria. J Pharmacogn 1 (1): 64-66.

Wiersum KF. 2006. Tropical homegardens. A time-tested example of sustainable agroforestry. In: Kumar BM, Nair PKR (eds.). Advances in Agroforestry. Springer, Netherlands.

Yuliawati NWP, Wiraatmaja IW, Yuswanti H. 2016. Identification and characterization of genetic resources of local fruits in Gianyar. Jurnal Agroekoteknologi Tropika (J Trop Agroecotechnol) 5 (3): 297-309. 